\title{
CAUSES OF FAILURES IN CIRCULAR CONCRETE SILO WALLS, PARTICULARLY UNDER ENVIRONMENTAL INFLUENCES
}

Juraj BILČÍK, Július ŠOLTÉSZ1', Lýdia LEPPAKORPI MATIAŠKOVÁ², Katarína GAJDOŠOVÁ'

\section{Abstract}

The paper reports the results of a case study for achieving longer service life and increasing the environmental sustainability of concrete silos. Damage mechanisms in concrete silo walls, and respectively in cylindrical structures (e.g., chimneys, cooling towers, and tanks), are widely diverse. The common causes of failures include those due to poor design considerations, construction deficiencies, non-compliance with operational rules and regulations, lack of maintenance, and insufficient and/ or corroded reinforcements, together with the environmental conditions affecting the walls. In addition to the ultimate limit state design, temperature-induced cracking may often be underestimated in the design of reinforced concrete silos, leading to premature deterioration and losses in serviceability. Cracks from environmental or service conditions facilitate the ingress of moisture and corrosive agents. Therefore, there is an increased interest in reducing the appearance of cracks and limiting their width. The aim of this paper is to highlight the synergistic effects in the design, construction, and operation of silo walls, particularly undervarying environmental influences. The research undertaken indicates that systematic errors can be identified and corrected.

\section{Address}

1* Dept. of Concrete Structures and Bridges, Faculty of Civil Engineering, Slovak University of Technology in Bratislava, Slovakia

${ }^{2}$ ISPO spol. s r. O., Engineering Structures, Bratislava, Slovakia

* Corresponding author: juraj.bilcik@stuba.sk

Key words

- Failure analysis,

- Thermal stress,

- Corrosion

- Cracks

- Spalling.

\section{INTRODUCTION}

Although organizations and individuals tend to focus on learning from success, research has shown that failure can yield crucial insights in various contexts that range from small mistakes and errors and accidents to large-scale disasters (Dahlin et al. 2018).

Understanding the environmental sustainability of a construction infrastructure is no longer an option; it is a requirement of any modern engineering endeavour. A thorough review of potential direct, indirect, and environmental actions must be a starting point when designing and determining the reliability of reinforced concrete structures. Silo walls resist forces and bending moments due to the loads applied (i.e., permanent loads, pressure from stored material, overpressures generated during filling or discharge, abrasion and impact loads, and asymmetrical flows as well as rat holing and bridging). Other potential loads, including seismic and wind loads, the potential expansion of stored material, and differential settlement of the foundation, should also be considered during the design process (Dogangun et al. 2009; ISO 13823 2008). Since silos are usually constructed in a natural environment, environmental influences (the physical and chemical effects of the ambient conditions) become one of the major factors that affect the durability of silos.

A silo wall is relatively thin with respect to the other dimensions of the cylinder, which is why environmental factors, namely, fluctuations in the ambient temperature, humidity, solar radiation, wind, snow, ice, and the presence of aggressive compounds in the atmosphere, have a significant adverse impact on its performance (Poukhonto 2003). The main deterioration mechanisms considered for a silo wall are the corrosion of the reinforcement and a chemical attack on the concrete, the temperature stresses induced by solar radiation, and the high temperature of the stored 
material. Associated changes in the temperature and gradients can lead to cracking of the concrete.

During the last two decades, many investigations have been undertaken regarding the effect of the cracking of concrete and corrosion of the reinforcement on the performance of concrete structures (Alonso et al. 1998, Al-Harthy et al. 2011, Li and Yang 2011, Heinrich and Schlicke 2018). The serviceability and durability of concrete structures may be adversely affected by excessive cracking. The cracking of concrete and the corrosion of the reinforcement should be limited to a level that will not impair the proper operation and durability of the structure or cause its appearance to be unacceptable (Litzner and Becker 1999). Large cracks may not only affect the serviceability and durability of a structure, but also its strength and stability by modifying the structural system.

Thermal actions and the resulting stresses on cylindrical concrete silos have been presented in various research papers. Experimental and numerical investigations of the temperature and stress distribution in silos subjected to grain pressures and the thermal gradient induced by solar gains have been conducted (Jofriet et al. 1991; Sfikas et al. 2017). Other valuable experimental research and numerical analyses have been carried out on storage silos under different temperature conditions (Diamoutene and Kaminski 2003; Lapko and Prusiel 2006; Chen et al. 2018).

Fortunately, silos typically demonstrate defects prior to their structural failure. Observing cracking patterns, concrete chunks lying around, delaminating and spalling of concrete, etc., can undoubtedly indicate that something unintended is happening with the silo. Cement storage silos have their own unique issues (e.g., thermal shock). These failures usually occur due to inadequate design, poor construction, improper operation, and/or lack of maintenance (Lynskey 2016; Sagarnaga 2018).

\section{FAILURES PARTICULARLY ASSOCIATED WITH ENVIRONMENTAL INFLUENCES}

The authors are presenting a case study to determine the causes of the failures of a group of four solitary cylindrical concrete silos. The cement storage silos were constructed from slip-formed concrete in the late 1970s. The targeted concrete strength class was $\mathrm{C} 25 / 30$ (characteristic compressive cylinder/cube strength). Each silo wall, which was $49.2 \mathrm{~m}$ tall, $10.8 \mathrm{~m}$ in diameter, and $0.25 \mathrm{~m}$ in thickness, gradually deteriorated over a period of about four decades. The wall reinforcement of each silo consists of two layers of horizontal reinforcement (from $\varnothing 10$ to $\varnothing 20 \mathrm{~mm}$ with varied spacing) and vertical reinforcement (from Ø14 to Ø22 $\mathrm{mm}$ with a spacing of $200 \mathrm{~mm}$ ) distributed uniformly throughout the wall's height. The spacing and diameter of the bars and the thickness of the concrete cover were checked and measured non-destructively with a cover meter in combination with direct measurement of the uncovered reinforcement.

The reinforced concrete wall of a silo is usually subjected to severe corrosion induced by carbonation (exposure class XC4) from the outside, mild corrosion (class XC1) from the inside, respectively and mild frost-thaw cycles from the outside (class XF1). According to EN 1992-1-1 (CEN 2004), the nominal depth of the concrete cover for class XC4 should be at least $c_{\text {nom }}=c_{\text {min }}$ $+\Delta c_{\mathrm{dev}}=30+10 \geq 40 \mathrm{~mm}$, where $\Delta c_{\mathrm{dev}}$ is an allowance in the design for deviations. The measured concrete cover of the horizontal reinforcement of the silos at issue was significantly less than specified and varied from 10 to $25 \mathrm{~mm}$, while the vertical re- inforcement varied from 25 to $40 \mathrm{~mm}$, respectively. The corrosion of the horizontal reinforcement was much more advanced than that of the vertical reinforcement.

After a thorough site inspection, it was confirmed that all four silos had experienced similar damage, i.e., deep concrete spalling and numerous significant horizontal and vertical cracks, as well as corrosion of the horizontal reinforcement (Fig. 1a). A fundamental part of the visual inspection was based on the measurement of the damage, which was digitally processed with CAD software (Table 1). The failures detected on the unrolled surface of the silo cylinder wall are presented in Fig. 1b.
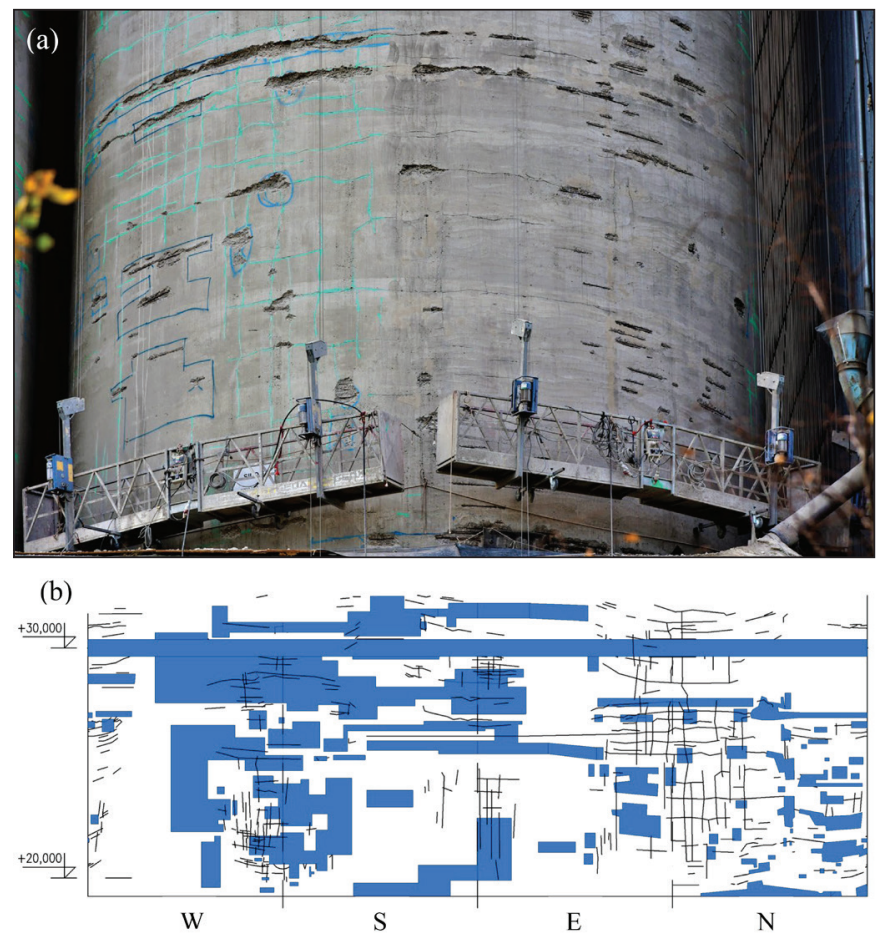

Fig. 1

(a) Visualisation of cracks and damaged areas on the silo wall; (b) The corresponding part of the unrolled silo wall with recorded cracks and damaged areas (with permission of Vertical Industrial)

The differences between the measured length of the cracks and damaged areas upon visual inspection before and after cleaning of the wall arise because the mechanical means (e.g., a high-pressure water jet) used to remove damaged surfaces revealed hidden faults associated with an increase in the length of cracks and damaged areas. The approximation coefficients $k 1$ and $k 2$ have been statistically evaluated in the past in an actual realization of the repairs on rotationally symmetrical high-rise structures (e.g., silos, chimneys, and cooling towers).

The compressive strength, strength class, modulus of elasticity, and carbonation depth of the concrete were determined from cores extracted from the silo wall; they are shown in Table 2. The carbonation depth was measured using a phenolphthalein indicator sprayed on a freshly split concrete core surface.

\subsection{Deep concrete spalling and delamination at the construction joints}

Deep concrete cavities of the silo walls at the construction joints were identified as the most serious structural problem. 
Tab. 1 The total length of the cracks and damaged areas in the four silo walls

\begin{tabular}{|c|c|c|c|c|c|c|}
\hline Silo No. & $\begin{array}{l}\text { Geodetically measured } \\
\text { length of cracks }(\mathrm{m})\end{array}$ & $\begin{array}{l}\text { Geodetically measured } \\
\text { damaged areas }\left(\mathrm{m}^{2}\right)\end{array}$ & $\begin{array}{c}\text { Coef- } \\
\text { ficient } k_{1}^{\text {a }}\end{array}$ & $\begin{array}{c}\text { Coefficient } \\
k_{2}^{\mathrm{b}}\end{array}$ & $\begin{array}{c}\text { Length of cracks } \\
. k_{1} \cdot k_{2}(\mathrm{~m})\end{array}$ & $\begin{array}{l}\text { Damaged areas } \\
. k_{1} \cdot k_{2}\left(\mathrm{~m}^{2}\right)\end{array}$ \\
\hline 1 & 324.0 & 894.0 & \multirow{5}{*}{1.15} & \multirow{5}{*}{1.3} & 484.4 & 1336.5 \\
\hline 2 & 386.0 & 987.0 & & & 577.1 & 1475.5 \\
\hline 3 & 379.0 & 968.0 & & & 566.6 & 1447.2 \\
\hline 4 & 352.0 & 944.0 & & & 526.2 & 1411.3 \\
\hline Mean value & 360.2 & 948.25 & & & 538.6 & 1417.6 \\
\hline
\end{tabular}

Tab. 2 Compressive strength, strength class, modulus of elasticity, and carbonation depth of the concrete after 41 years of operation

\begin{tabular}{|c|c|c|c|c|c|}
\hline Silo No. & $\begin{array}{c}\text { Cylinder strength } \\
(\mathrm{MPa})\end{array}$ & $\begin{array}{c}\text { Converted cube } \\
\text { strength }(\mathrm{MPa})\end{array}$ & Strength class & $\begin{array}{c}\text { Modulus of elasticity } \\
(\mathrm{GPa})\end{array}$ & $\begin{array}{c}\text { Carbonation depth } \\
(\mathrm{mm})\end{array}$ \\
\hline 1 & 38.52 & 48.15 & $\mathrm{C} 35 / 45$ & 32.08 & $20 \sim 30$ \\
\hline 2 & 43.57 & 54.46 & $\mathrm{C} 40 / 50$ & 34.51 & $15 \sim 20$ \\
\hline 3 & 41.30 & 51.62 & $\mathrm{C} 40 / 50$ & 34.98 & $15 \sim 20$ \\
\hline 4 & 43.08 & 53.84 & $\mathrm{C} 40 / 50$ & 34.45 & $15 \sim 20$ \\
\hline Mean value & 41.62 & 52.03 & - & 34.01 & $16 \sim 22$ \\
\hline
\end{tabular}
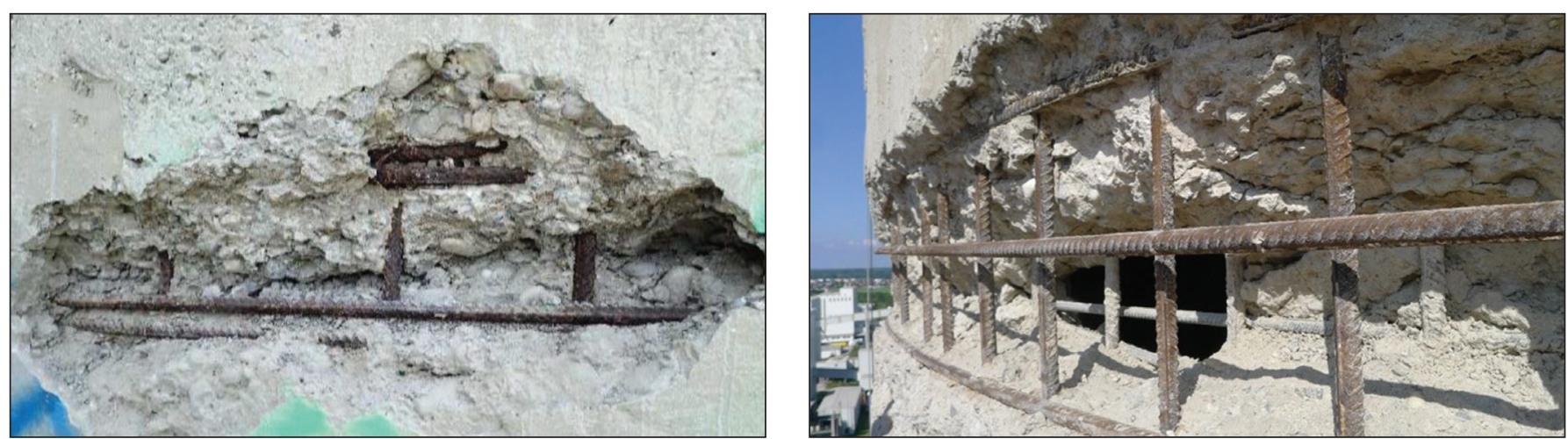

Fig. 2 Deep concrete cavities and a hole at the construction joints (with permission of Vertical Industrial)

Figure 2 shows a closer look at a silo wall hole and cavities at a construction joint. The concrete spalls, slipform lifts, poor consolidation, and improper or insufficient curing may have been the main factors that caused the serious structural damage, thus weakening the silo's structural capacity. Issues of this nature require repair sooner rather than later.

The investigation has confirmed the presence of at least two circumferential deep areas of concrete spalling and slipform lifts along the construction joints at heights of $38.0 \mathrm{~m}$ and $63.0 \mathrm{~m}$ in all four silos. Overall, that means more than $68 \mathrm{~m}$ of substantial structural damage to each of the silo walls.

\subsection{Deterioration model - cracking}

The appearance of small cracks in concrete is more or less unavoidable and does not necessarily result in the risk of collapse for the structure. Cracked concrete causes the corrosion process to initiate much faster than uncracked concrete. Cracks may adversely affect the durability of the concrete by providing easy access for aggressive agents. Furthermore, cracks can significantly increase the ingress of moisture and impair the serviceability of certain structures such as tanks and containments. Based on a combination of theoretical and experimental results (Holland et al. 2016; Al-Galawi et al. 2016; Shaikh 2018; Alarab et al. 2019), it has been concluded that the thickness of a concrete cover and its quality (e.g., the water-to-cement ratio) are the most significant factors influencing the initiation and propagation of reinforcement corrosion. The width and depth of a crack can also have a major influence, particularly regarding the initiation of corrosion.

The main causes of cracks in silo walls are thermal loads, concrete shrinkage, reinforcement corrosion or simple mechanical overloading (Nilsson et al. 2016).

\subsubsection{Shallow horizontal cracks with spalling edges}

The shallow cracks along the horizontal reinforcements mainly occurred due to the corrosion of the steel in the silo walls investigated (Fig. 3). A low concrete cover has been identified as a ma- 


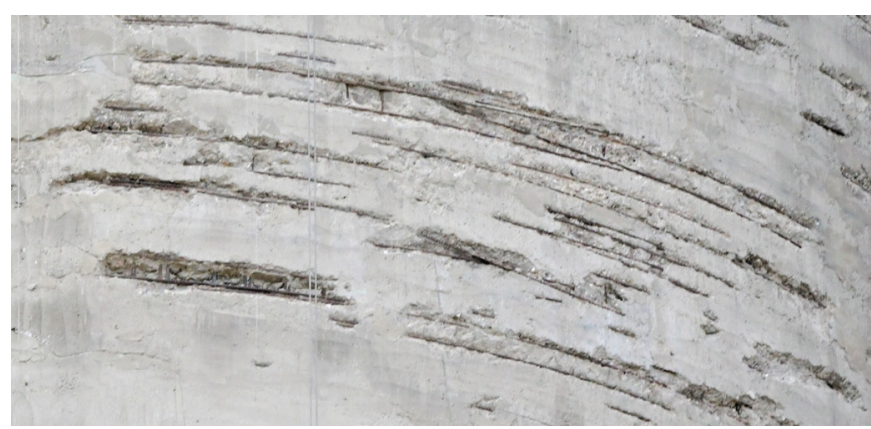

Fig. 3 Shallow horizontal cracks with spalling edges in a silo wall

(a)

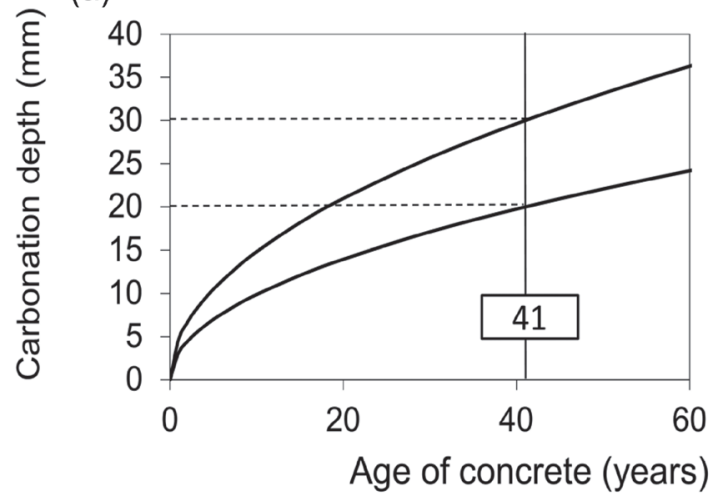

(b)

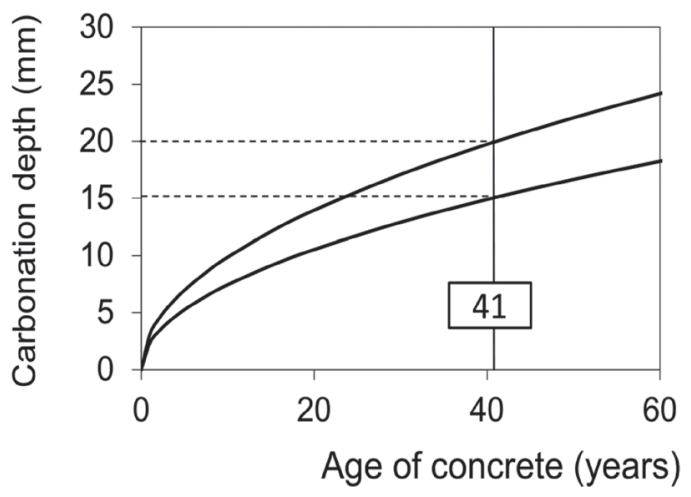

Fig. 4 Predicted course and dispersion of the depth of carbonation in silo walls after 41 years of operation:

(a) Silo No. 1; (b) Silo Nos. 2, 3, and 4

jor cause of the premature depassivation of a steel reinforcement and its subsequent corrosion. An inadequate concrete cover will speed up not only the depassivation of a reinforcement but also the ingress of moisture and oxygen, i.e., the corrosion rate. Reinforcement corrosion decreases the effective steel area and reduces the bond strength (Prota et al. 2003; Moodi et al. 2020).

The reaction of calcium hydroxide, $\mathrm{Ca}(\mathrm{OH})_{2}$, with carbon dioxide, $\mathrm{CO}_{2}$, from the atmosphere is termed the "carbonation" of concrete. Carbonation is considered to be the cause most responsible for the reduction of the $\mathrm{pH}$ value of the pore solution of the concrete, which normally being around $12.6-13$, decreases to less than 9. This fall in the value of the $\mathrm{pH}$ is responsible for the depassivation of the reinforcement in concrete, further exposing the rebar to potential threats of corrosion (Papadakis et al. 1992; Chi et al. 2002; ACI 201.2R-16; Hussain et al. 2016).
For the diffusion of $\mathrm{CO}_{2}$ through concrete and assuming a stationary diffusion, Fick's first law of diffusion applies. The ingress of the carbonation front in the concrete may be assumed to obey the following equation:

$$
x_{\mathrm{c}}(t)=W(t) \cdot k \cdot \sqrt{t}=\sqrt{D_{\mathrm{c}} \cdot t}
$$

where $x_{c}$ is the depth of the carbonation front $(\mathrm{m}) ; W(t)$ is the function of the meso-climatic conditions; $k$ is the carbonation rate constant that reflects aspects of the permeability of the concrete (such as the w/c-ratio, type of cement) and the influence of the basic environmental conditions (such as the mean relative humidity and the concentration of $\mathrm{CO}_{2}$ ); and $t$ is the time (s).

In order to assess the residual service life of the silos investigated, the diffusion coefficient $D_{c}$ of $\mathrm{CO}_{2}$ in the concrete $\left(\mathrm{m}^{2} . \mathrm{s}^{-1}\right)$ was derived from measurements of the depth of carbonation on the walls after 41 years of a silo's operation in a cement plant (fib 2006, fib 2013). The older the silo, the more accurate the prediction model of the depth of the carbonation. Figure 4 illustrates the predicted course and dispersion of the depth of carbonation of the concrete in the silo walls.

The design service life is modelled as the initiation and propagation stages of the reinforcement corrosion, the consequences of the reinforcement corrosion, and finally, the structure's serviceability and ultimate failures (Figure 5). The end of the technical service life of a structure subject to deterioration caused by reinforcement corrosion could potentially be defined by one, or possibly more, of the limit states below, which are related to the Serviceability Limit States (SLS) or Ultimate Limit States (ULS).

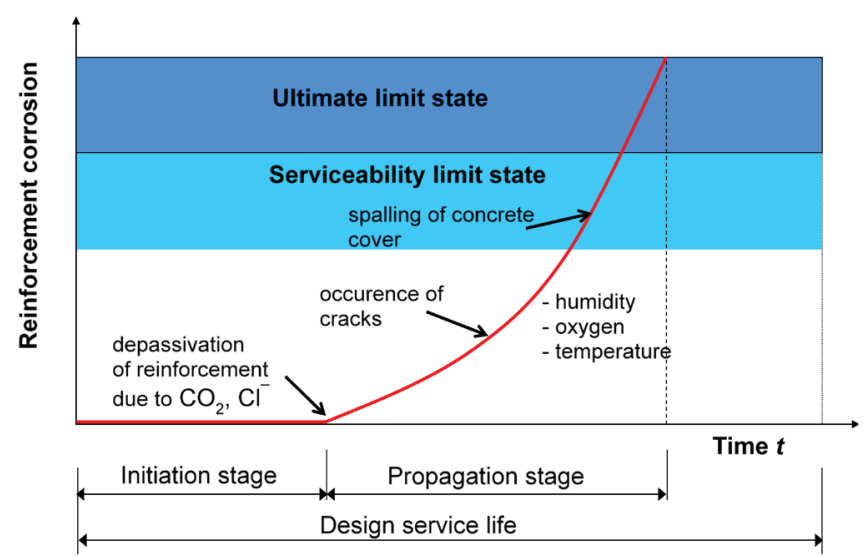

Fig. 5 Design service life of concrete structures due to the reinforcement corrosion

The corrosion of reinforcement results in the formation of various corrosion products due to the process of oxidation and causes an increase in the volume. Depending on the level of oxidation and the availability of moisture, corrosion products have a specific volume ranging from about two to six times that of the iron consumed (Savija et al. 2013; Li et al. 2017). This increase in volume generates radial stress (pressure) on the surrounding concrete at the interface between the reinforcement and concrete, eventually leading to the cover cracking along the line of the bar. It is widely accepted that the state of cover cracking induced by corrosion is identified as the serviceability limit state of reinforced concrete structures.

There are different views as to the definition of a 'limit crack width'. For example, $0.3-0.5 \mathrm{~mm}$ is suggested for a durability 

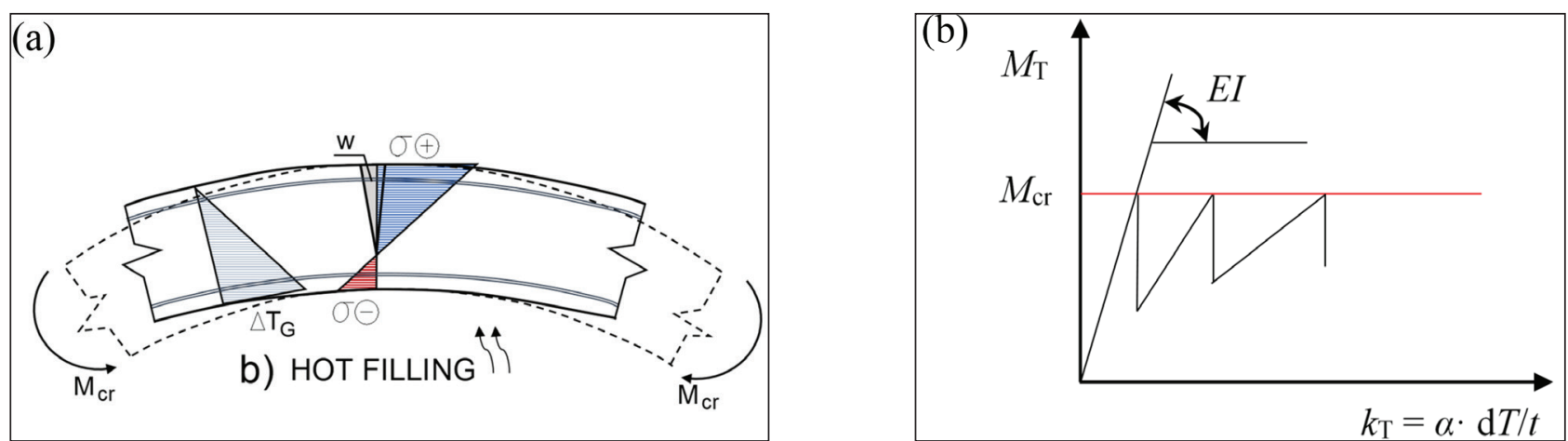

Fig. 6 (a) The temperature gradient ( $\Delta T)$, stress distribution ( $\sigma)$, resulting cracking bending moment (Mcr) and crack (w); (b) The relationship between curvature $k$ and bending moment $M$ is represented by the zig-zag diagram

limit state and $0.8 \mathrm{~mm}$ for aesthetic and serviceability requirements. Asset owners will generally have their own policies on the size of the limit crack width, depending on a number of factors, including local regulations and the intended function of the structure. A limit crack width of $1.0 \mathrm{~mm}$ is assumed to represent severe cracking (Steward and Mullard 2007; Lu and Liu 2010).

\subsubsection{Vertical cracks with sharp edges}

Temperature differences $(\Delta T)$ are encountered in silo walls due to heating by hot cement (cement after cooling is stored at temperatures ranging from 70 to $100{ }^{\circ} \mathrm{C}$ ) or as a result of external weather influences (frost and solar radiation). As a consequence, bending moments are activated which, starting approximately from $\Delta T=20^{\circ} \mathrm{C}$, lead to the formation of vertical cracks with sharp edges in a cylindrical wall (Fig. 7a). Analytical and numerical investigations have been carried out to verify this assumption.

The largest temperature gradients in silo walls are expected during winter conditions. A silo with a hot filling on a cold winter day experiences a temperature gradient $\Delta T$ over the width of the wall. A temperature gradient with a hotter inner surface causes vertical cracks $(w)$ on the outer surface (Fig. 6a).

The first cracks occur when the bending moment, which is mostly activated by temperature difference $\Delta T$, reaches the value $M_{\text {cr }}$ (Fig. 6b). A further increase of $\Delta T$ leads to more cracks without any change of $M_{\text {cr }}$ (Noakowski et al. 2015).

An analytical model for the calculation of the temperature gradient that triggers vertical cracks is based on the condition of the equality of a curvature due to temperature gradient $k_{T}$ and bending moment $k_{M}$ :

$$
k_{T}=k_{M} \rightarrow \frac{\alpha_{T} \cdot \Delta T}{t}=\frac{2 f_{c t m, f l}}{E_{c m} \cdot t} \rightarrow \Delta T=\frac{2 \cdot f_{c t m, f l}}{\alpha_{T} \cdot E_{c m}}
$$

where:

$f_{\mathrm{ctm}, \mathrm{fl}}$ is the mean flexural tensile strength
$f_{\mathrm{ctm}, \mathrm{fl}}=\max \left((1.6-\mathrm{t} / 1000) f_{\mathrm{ctm}} ; f_{\mathrm{ctm}}\right)$ in $\mathrm{MPa}$,

$\alpha \mathrm{T}$ is the linear coefficient of thermal expansion for concrete in $\mathrm{K}^{-1}$,

$E_{\mathrm{cm}}$ is the secant modulus of elasticity of concrete in $\mathrm{MPa}$,

$t \quad$ is the thickness of the silo wall in $\mathrm{m}$.

The temperature gradients, which could initiate vertical cracks for different concrete strength classes over 41 years of the silos' operation, are given in Table 3.

To show the significance of thermal loading, a numerical analysis was performed for a case study of a silo filled with hot cement at a temperature of $T_{\mathrm{cem}}=90^{\circ}$ and an outside air temperature of $T_{\text {air,e }}=-11^{\circ} \mathrm{C}$. The evolution of the resulting thermal gradients over the width of the wall with a thickness of $0.25 \mathrm{~m}$ after filling is presented in Fig. 7b. Initially, the temperature course was nonlinear, and the absolute differences in temperature between the surfaces reached $44{ }^{\circ} \mathrm{C}$, which posed a significant risk of cracking on the outer surface. The temperatures balanced out into a linear course within the first 9 hours, resulting in a gradient of $\Delta T=23^{\circ} \mathrm{C}$. After this point, the cooling process gradually slowed down. After 36 hours, the gradients were already below the critical value of $\Delta T=20^{\circ} \mathrm{C}$.

After cooling, thermal cracks are expected to close, assuming that a satisfactory amount of reinforcement has been provided. Older silos with insufficient horizontal hoops do not always fulfil these criteria; wide through cracks are the consequence.

In concrete silos designed for the serviceability limit state, cracking should be limited to prevent water ingress at any time. Silos holding dry materials sensitive to moisture (e.g., cement or clinker) should be designed according to EN 1992-3 (CEN 2006b), Class 3: no leakage permitted.

Tab. 3 Parameters for calculation of the temperature gradient that initiates vertical cracks

\begin{tabular}{|c|c|c|c|c|}
\hline Concrete strength class & $\begin{array}{c}\text { Mean tensile strength of } \\
\text { concrete } f_{\mathrm{ctm}}(\mathrm{MPa})\end{array}$ & $\begin{array}{c}\text { Mean flexural tensile } \\
\text { strength } f_{\mathrm{ctm}, \mathrm{fl}}(\mathrm{MPa})\end{array}$ & $\begin{array}{c}\text { Secant modulus of } \\
\text { elasticity of concrete } \\
E_{\mathrm{cm}}(\mathrm{GPa})\end{array}$ & $\begin{array}{c}\text { Temperature gradient } \Delta T\left({ }^{\circ} \mathrm{C}\right) \\
\text { which could initiate vertical } \\
\text { cracks in silo wall }\end{array}$ \\
\hline $\mathrm{C} 25 / 30$ & 2.6 & 3.5 & 31 & 33 \\
\hline $\mathrm{C} 30 / 37$ & 2.9 & 3.9 & 34 & 22.5 \\
\hline $\mathrm{C} 35 / 45$ & 3.2 & 4.3 & 35 & 23.6 \\
\hline $\mathrm{C} 40 / 50$ & 3.5 & 4.7 & & 26.3 \\
\hline
\end{tabular}


(a)

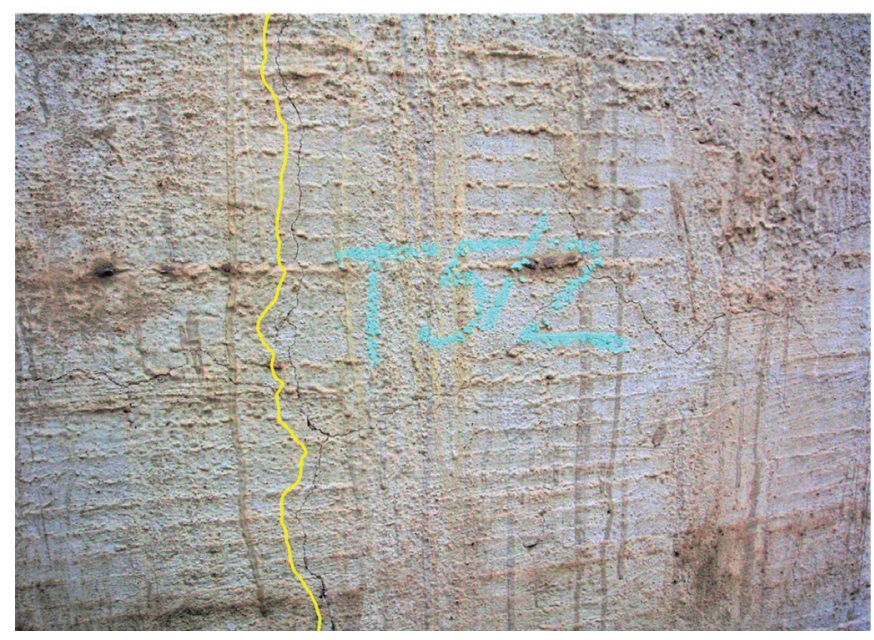

(b)

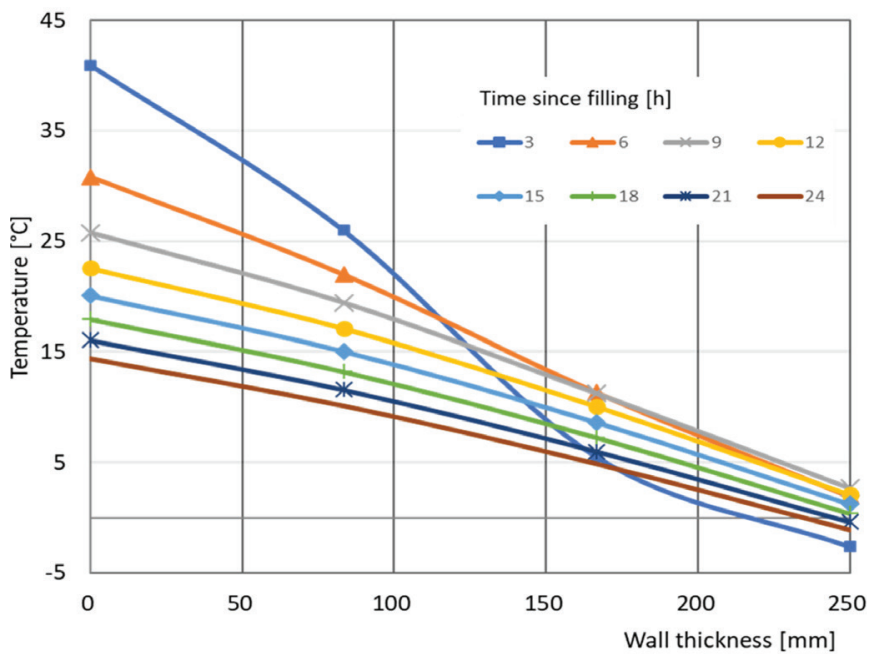

Fig. 7 (a) A vertical crack with sharp edges in a silo wall; (b) Evolution of the temperature gradients over time after filling with hot cement (Matiaskova et. al. 2020)

Where thermal stress adds significantly to stress due to the material stored, additional reinforcement is required. In places where the thermal stress exceeds the stress from the stored material, a sufficient reinforcement for crack control should be provided. In walls with two layers of reinforcement, reinforcement to resist thermal bending moments should be added to the layer nearest the colder face (ACI 313-16).

\section{CONCLUSIONS}

Silos can have a long life span and operate reliably if they are properly designed, constructed, and maintained. Great progress has been made in the last two decades in providing silo design guidance according to EN 1991-4 (CEN 2006a).

Based on the results of the investigation, the technical documentation, visual inspection and testing of the four cement silos, the following conclusions can be drawn:

1. Construction joints in a slip form silo wall are a weak point and should not be permitted unless indicated on the contract documents or specifically approved by the licensed designer responsible for the silo design. Slipform lifts, inadequate consolidation, and curing may be the main factors that cause deep spalling of weak concrete in walls at construction joints.

2. The carbonation model, with diffusion coefficient $D_{c}$ as the key variable, was determined from measurements of the depth of carbonation on the walls after 41 years of the silos' operation in a cement plant. The modified carbonation model incorporates the influence of the environmental and operational conditions and is proposed to predict the residual service life with a fair degree of accuracy.

3. A thorough site inspection confirmed that steel corrosion, along with horizontal reinforcement with an inadequate concrete cover, is the main cause of the formation of horizontal cracks with spalling edges in the silo walls.

4. An analytical model proved that temperature gradients are one of the main causes of the formation of vertical cracks with sharp edges. Table 3 shows that a temperature gradient between $22-27^{\circ} \mathrm{C}$, depending on the concrete strength class, could initiate vertical cracks in the silo walls investigated.

5. Numerical investigations showed the evolution of the resulting thermal gradients over the width of the wall after filling with hot cement at a temperature of $T_{\text {cem }}=90^{\circ}$ and the outside air temperature of $T_{\text {air,e }}=-11^{\circ} \mathrm{C}$. The initially nonlinear function balanced out into a linear course within the first 9 hours.

6. Cracks are one of the early warning signs of the impending failure of a silo wall. The entire outside of a silo should be scanned at least annually to determine if new cracks have developed or if the existing cracks have increased in width since the last visual inspection. An inspection program administered by experienced engineers is an important tool to maintain the reliability of a silo structure. The first logical step towards ensuring the reliability of a cracked silo wall is a single-component polyurethane injection resin to seal any through cracks in the wall.

\section{Acknowledgements}

This work was supported by the Slovak Research and Development Agency under Contract No. APVV-17-204 and the Scientific Grant Agency VEGA under Contract No. VEGA 1/0654/20. 


\section{REFERENCES}

ACI (American Concrete Institute). (2008) Guide to Durable Concrete. ACI 201.2R-16, Farmington Hills, MI., USA

ACI (American Concrete Institute). (2016) Design Specification for Concrete Silos and Stacking Tubes for Storing Granular Materials and Commentary. ACI 313-16, Farmington Hills, MI., USA

Alarab, L.A. - Poursaee, A. - Ross, B.E. (2019) An experimental method for evaluating reinforcement corrosion in cracked concrete. Journal of Structural Integrity and Maintenance, 4(1), Taylor \& Francis, pp. 43-50. doi: https://doi.org/10.1080/24705314. 2019.1565058

Al-Galawi, N.M. - Al-Tameemi, A.H.H. - Al-Jarrah, S.H. (2016) Effect of Age and Concrete Cover Thickness on Steel Reinforcement Corrosion at Splash Zone in Reinforced Concrete Hydraulic Structures. International Journal of Scientific \& Technology Research, 5(9), pp. 129-133. https://pdfs.semanticscholar.org/f501/4ff2ff08af52ee9fceb82d89c09a3d43f530. pdf?_ga=2.170640224.1947854787.1575991952 1203245428.1575879417

Al-Harthy, A.S. - Stewart, M.G. - Mullard, J. (2011) Concrete cover cracking caused by steel reinforcement corrosion. Magazine of Concrete Research. 63(9), pp. 655-667. https://pdfs.semanticscholar.org/9ad8/a6ac957741b48c7c17a92d6b2b431a6896e5.pdf.

Alonso, C. - Andrade, C. - Rodriguez, J. - Diez, J.M. (1998) Factors controlling cracking of concrete affected by reinforcement corrosion. Materials and Structures, 31, pp. 435-441. https://link. springer.com/content/pdf/10.1007\%2FBF02480466.pdf

CEN (European Committee for Standardization) (2004) Design of concrete structures - Part 1-1: General rules and rules for buildings. EN 1992-1-1, Brussels. doi: https://www.phd.eng.br/ wp-content/uploads/2015/12/en.1992.1.1.2004.pdf.

CEN (European Committee for Standardization) (2006). Actions on structures - Part 4: Silos and tanks. EN 1991-4, Brussels.

CEN (European Committee for Standardization) (2006) Design of concrete structures - Part 3: Liquid retaining and containment structures. EN 1992-3, Brussels.

Chen Z., Li X. - Yang Y. - Zhao S. - Fu Z. (2018) Experimental and numerical investigation of the effect of temperature patterns on behavior of large scale silo. 91(1), Engineering Failure Analysis, pp. 543-553. doi: https://doi.org/10.1016/j.engfailanal.2018.04.043.

Chi, J.M. - Huang, R. - Yang, C.C. (2002) Effects of Carbonation on Mechanical Properties and Durability of Concrete Using Accelerated Testing Method. Journal of Marine Science and Technology, 10(1), pp. 14-20. https://jmst.ntou.edu.tw/marine/10-1/14-20.pdf

Dahlin, K.B. - Chuang, Y. - Roulet, T.J. (2018) Opportunity, Motivation, and Ability to Learn from Failures and Errors: Review, Synthesis, and Ways to Move Forward. Academy of Management Annals, 12(1), pp. 252-277. doi: https://doi.org/10.5465/ annals.2016.0049.

Diamoutene, K. - Kaminski, M. (2003) Investigation of temperature and strain distribution in reinforced-concrete wall of a rapeseed storage silo. Structural Concrete, 4(3), pp. 109-116. doi: https:// www.icevirtuallibrary.com/doi/abs/10.1680/stco.2003.4.3.109
Dogangun, A. - Karaca, Z. - Durmus, A. - Sezen, H. (2009) Cause of Damage and Failures in Silo Structures. ASCE J. of Performance of Constructed Fac. 23(2), pp. 65-71. https://ascelibrary. org/doi/full/10.1061/\%28ASCE\%290887-3828\%282009\%2923 $\% 3 \mathrm{~A} 2 \% 2865 \% 29$

fib (International Federation for Structural Concrete) (2006) Model Code for Service Life Design, fib Bulletin No 34. https:// www.fib-international.org/publications/fib-bulletins/model-codefor-service-life-design-pdf-detail.html

fib (International Federation for Structural Concrete) (2013) Model Code for Concrete Structures 2010.” Ernst \& Sohn. doi: https:// onlinelibrary.wiley.com/doi/book/10.1002/9783433604090.

Heinrich, P.J. - Schlicke D. (2018) Crack Assessment of a Very Thick and Bloc-Like Concrete Member, Slovak Journal of Civil Engineering, 26(3), pp. 41-48. doi: 10.2478/sjce-2018-0019

Holland, R.B. - Kurtis, K.E. - Kahn, L.F. (2016) Effect of different concrete materials on the corrosion of the embedded reinforcing steel. Corrosion of Steel in Concrete Structures. Woodhead Publishing Series in Civil Engineering, No. 61, pp. 131-147. doi: https://doi.org/10.1016/B978-1-78242-381-2.00007-9

Hussain, S. - Bhunia, D. - Singh, S.B. (2016) Assessment of carbonation depth under natural and accelerated carbonation conditions. Indian Concrete Journal, No. 11, pp. 57-64. https://www. researchgate.net/publication/304526735

ISO (International Organization for Standardization) (2008) General principles on the design of structures for durability. ISO 13823, Geneva.

Jofriet, J.C. - Jiang, S. - Tang, S.W. (1991) Finite element prediction of temperature gradients in walls of cylindrical concrete storage structures. Canadian Journal of Civil Engineering, 18(1), 12-19. doi: https://doi.org/10.1139/191-002

Lapko, A. - Prusiel, J.A. (2006) Analysis of thermal effects in grouped silos of grain elevators. Int. Agrophysics, 20(4), pp. 301307. http://www.international-agrophysics.org/Analysis-of-thermal-effects-in-grouped-silos-of-grain-elevators, 106615,0,2.html

Li, C.Q. - Yang, S.T. (2011) Prediction of Concrete Crack Width under Combined Reinforcement Corrosion and Applied Load. Journal of Engineering Mechanics, ASCE, 137(11), 722-731. doi: https://10.1061/(ASCE)EM.1943-7889.0000289

Li, W., Xu, Ch., Ho, S.C.M., Wang, B. and Song, G. (2017) Monitoring Concrete Deterioration Due to Reinforcement Corrosion by Integrating Acoustic Emission and FBG Strain Measurements. Sensors (Basel), 17(3): 657. doi: http://doi:10.3390/s17030657

Litzner, H. - Becker, A. (1999) Design of concrete structures for durability and strength to Eurocode 2. Materials and Structures, 32(6), 323-330. doi: https://link.springer.com/content/ pdf/10.1007/BF02479623.pdf

Lu, C.H. and Liu, R.G. (2010) A model for predicting time to corrosion-induced cover cracking in reinforced concrete structures. Fracture Mechanics of Concrete and Concrete Structures - Assessment, Durability, Monitoring and Retrofitting of Concrete Structures- B. H. Oh, et al. (eds.), Korea Concrete Institute, Seoul, 967-975, https://framcos.org/FraMCoS-7/07-17.pdf 
Lynskey, G. (2016) Too Big to Fail? Proceedings of the IEEE $4^{\text {th }}$ International Conference on Collaboration and Internet Computing, Nov. 1-3, Pittsburgh, PA., USA

Matiaskova, L. - Bilcik, J. - Soltesz, J. (2020) Failure analysis of reinforced concrete walls of cylindrical silos under elevated temperatures. Engineering Failure Analysis, Elsevier, https://doi. org/10.1016/j.engfailanal.2019.104281

Moodi, Y. - Sohrabi, M.R. - Mousavi, S.R. (2020) Effects of stirrups in spliced region on the bond strength of corroded splices in reinforced concrete ( $R C$ ) beams. Construction and Building Materials, Elsevier, 230(1), pp. 1-9. doi: https://doi.org/10.1016/j. conbuildmat.2019.116873.

Nilsson, L.O. - Kamali-Bernard, S. - Santhanam, M. (2016) $D u$ rability of Reinforced Concrete Structures and Penetrability. In: State of the Art Report: Performance-Based Specifications and Control of Concrete Durability, RILEM TC 230-PSC. Springer, pp. 9-17. doi: http://DOI10.1007/978-94-017-7309-6

Noakowski, P. - Harling, A. - Zdanowicz, L. (2015) Background, Reliability and Appliance of the Crack Width Prediction Method According to EN 13084. Architecture - Civil Engineering Environment, No. 2/2015, pp. 61-70. http://www.acee-journal. $\mathrm{pl} / 1,7,35$,Issues.html

Papadakis, V.G. - Fardis, M.N. - Vayenas, C.G. (1992) Effect of Composition, Environmental Factors and Cement Lime Mortar Coating on Concrete Carbonation. Materials and Structures, 25(149), Springer Nature Switzerland AG, pp. 293-304. doi: https://doi.org/10.1007/BF02472670.

Poukhonto, L.M. (2003) Durability of Concrete Structures and Constructions. Silos, Bunkers, Reservoirs, Water Towers, Retaining Walls, Balkema Publishers, The Netherlands. https:// books.google.sk/books?id=bvW8sGEW114C\&dq=concrete + silos + under + environmental + influences $\&$ hl $=$ sk\&source $=\mathrm{gbs}$ navlinks_s
Prota, A. - Parretti, R. - Nanni, A. (2003) Upgrade of RC Silos Using Near Surface Mounted FRP Composites. L'Industria Italiana del Cemento, pp. 170-182.

Sagarnaga, J. C. (2018) Concrete Silo Failures Due to Design Errors. Proc. of the Eighth Congress on Forensic Engineering, ASCE, 696-706. doi: https://doi.org/10.1061/9780784482018. fm.

Savija, B. - Lukovic, M. - Pacheco, J. - Schlangen, E. (2013) Cracking of the concrete cover due to reinforcement corrosion: A two dimensional lattice model study. Construction and Building Materials, 44, pp. 626-638. https://www.researchgate.net/publication/257389862.

Sfikas, I.P. - Ingham, J. - Baber, J. (2017) Using finite-element analysis to assess the thermal behaviour of concrete structures, Concrete, Feb. 2017, pp. 50-52. London, UK. doi: https://www.researchgate.net/publication/313661324.

Shaikh, F.U.A. (2018) Effect of Cracking on Corrosion of Steel in Concrete. Int. J. Concr. Struct. Mater., 12(3). pp. 29-133. doi: http://DOI10.1186/s40069-018-0234-y

Steward, G.M. - Mullard, J.A. (2007) Spatial time-dependent reliability analysis of corrosion damage and the timing of first repair for $R C$ structures. Engineering Structures, 29(7), pp. 1457-1464. doi: http://doi:10.1016/j. engstruct.2006.09.004 